ROCZNIKI NAUK PRAWNYCH

Tom XXXI, numer $1-2021$

DOI: https://doi.org/10.18290/rnp21311-4

\title{
ZWROT KOSZTÓW PODRÓŻY PRZYSŁUGUJĄCY ŚWIADKOWI W TRYBIE ART. 618A K.P.K. W KONTEKŚCIE STANU EPIDEMII SARS-COV-2
}

\section{WPROWADZENIE}

Zgodnie z art. 618a k.p.k. świadkowi przysługuje zwrot kosztów podróży - z miejsca jego zamieszkania do miejsca wykonywania czynności postępowania na wezwanie sądu lub organu prowadzącego postępowanie przygotowawcze - w wysokości rzeczywiście poniesionych racjonalnych i celowych kosztów przejazdu własnym samochodem lub innym odpowiednim środkiem transportu. Wysokość ww. kosztów świadek powinien należycie wykazać. Przepis ten został wprowadzony ustawą o zmianie ustawy - Kodeks postępowania karnego oraz niektórych innych ustaw ${ }^{1}$. Nowelizacja przepisów Kodeksu postępowania karnego w zakresie przepisów dotyczących zwrotu świadkowi kosztów podróży była konsekwencją wyroku Trybunału Konstytucyjnego z dnia 22 marca 2011 r. $^{2}$, w którym Trybunał uznał, iż art. 4 ust. 1 dekretu z dnia 26 października 1950 r. o należnościach świadków, biegłych i stron w postępowaniu sądowym (Dz.U. Nr 49, poz. 445 z późn. zm.) jest niezgodny z art. 64 ust. 2 Konstytucji Rzeczypospolitej Polskiej. Trybunał orzekł jednak, że przepis traci moc obowiązującą z upływem dwunastu miesięcy od dnia ogłoszenia wyroku, co umożliwiało ustawodawcy przeprowadzenie procedury

Dr JAKUB KoSOwSKI - adiunkt, Katedra Postępowania Karnego, Instytut Nauk Prawnych, Wydział Prawa i Administracji Uniwersytetu Marii Curie-Skłodowskiej w Lublinie, pl. M. Curie- Skłodowskiej 5, 20-031 Lublin; e-mail: jakub.kosowski@poczta.umcs.lublin.pl; https://orcid.org/00000001-6888-5771.

${ }^{1}$ Ustawa z dnia 31 sierpnia 2012 r. o zmianie ustawy - Kodeks postępowania karnego oraz niektórych innych ustaw (Dz.U. z 2012 r., poz. 1101).

${ }^{2}$ Wyrok Trybunału Konstytucyjnego z dnia 22 marca 2011 r., SK 13/08, LEX nr 785597. 
legislacyjnej z odpowiednim wyprzedzeniem. W uzasadnieniu przytoczonego wyroku Trybunał słusznie zauważył, że

kwestionowany w niniejszej sprawie przepis jest wyrazem tego, że ustawodawca przyjął kryterium różnicowania wysokości zwrotu kosztów podróży świadków w postaci rodzaju postępowania, do którego zostali wezwani. Dokonana ocena tego kryterium z punktu widzenia spełnienia wymogów dopuszczalnego przez Konstytucję odstępstwa od zasady równości uzasadnia sformułowanie wniosku, że w tym przypadku nie zostały one spełnione. Przyjęte zróżnicowanie zasad zwrotu kosztów podróży w zależności od rodzaju procedury w żaden sposób nie wiąże się z celem regulacji prawnej, jakim jest zapewnienie zwrotu poniesionych przez świadka kosztów udziału w postępowaniu. Trudno również określić interes, któremu ma służyć przyjęte różnicowanie, a tym samym wskazać argumenty na rzecz preferencyjnego traktowania zwrotu kosztów podróży świadków stawiających się na wezwanie w sprawie cywilnej ${ }^{3}$.

Wprowadzony w 2012 r. art. 618a k.p.k., miał więc za zadanie dostosowanie zasad zwrotu świadkowi kosztów podróży do współczesnych realiów.

Analiza art. 618a k.p.k. wymaga odniesienia się do dwóch kluczowych zagadnień. Pierwsze z nich to miejsce zamieszkania, drugie zaś dotyczy wyboru środka transportu. Zagadnienia te wymagają rozważenia także z perspektywy stanu epidemii SARS-CoV-2 i elektronizacji postępowania karnego.

\section{MIEJSCA ZAMIESZKANIA ŚWIADKA}

Zgodnie z art. 618a k.p.k. świadkowi przysługuje zwrot kosztów podróży z miejsca zamieszkania do miejsca wykonywania czynności. O ile wskazanie miejsca wykonywania czynności nie będzie generowało trudności po stronie organu procesowego, o tyle wykazanie miejsca zamieszkania wymaga szerszego komentarza. Art. 25 Kodeksu cywilnego wskazuje, że miejscem zamieszkania osoby fizycznej jest miejscowość, w której osoba ta przebywa z zamiarem stałego pobytu. Miejsce zamieszkania należy więc odróżnić od miejsca zameldowania. Zgodnie $\mathrm{z}$ ustawą o ewidencji ludności ${ }^{4}$ obywatel polski przebywający na terytorium Rzeczypospolitej Polskiej jest obowiązany wykonywać obowiązek meldunkowy, który polega m.in. na: zameldowaniu

\footnotetext{
${ }^{3}$ Uzasadnienie wyroku Trybunału Konstytucyjnego z dnia 22 marca 2011 r., SK 13/08, LEX nr 785597.

${ }^{4}$ Ustawa z dnia 24 września 2010 r. o ewidencji ludności, t.j. Dz.U. z 2019 r., poz. 1397 z późn. zm.
} 
się w miejscu pobytu stałego lub czasowego. Pobytem stałym jest natomiast zamieszkanie $\mathrm{w}$ określonej miejscowości pod oznaczonym adresem z zamiarem stałego przebywania. Analiza obydwu definicji ustawowych prowadzi do wniosku, iż są one do siebie zbliżone. W praktyce częstym zjawiskiem jest natomiast wskazywanie innego adresu zameldowania a innego adresu zamieszkania. Adres zameldowania nie przesądza o miejscu zamieszkania, lecz w orzecznictwie wskazano, że niejednokrotnie będzie stanowić wskazówkę przy ocenie istnienia przesłanek określonych w art. 25 Kodeksu cywilnego 5 . K. Dudka ${ }^{6}$ wskazała, że o miejscu zamieszkania decydują dwa czynniki: zewnętrzny (fakt przebywania) i wewnętrzny (zamiar stałego pobytu). Zdaniem cytowanej autorki: „przebywanie to czynnik trwały, choć niekoniecznie ciągły, związany z zamiarem stałego pobytu, tj. nietymczasowego, nieokazjonalnego. Natomiast zamiar stałego pobytu musi być określony na podstawie obiektywnych, możliwych do stwierdzenia okoliczności" ". Słusznie zauważył także K. Eichstaedt, że „o zamieszkiwaniu w danej miejscowości można mówić wówczas, gdy występujące okoliczności pozwalają przeciętnemu obserwatorowi na wyciągnięcie wniosków, że określona miejscowość jest głównym ośrodkiem aktywności życiowej określonej dorosłej osoby fizycznej” ${ }^{8}$. Organ procesowy będzie więc dokonywał analizy powyższej kwestii na podstawie oświadczenia świadka. W tym zakresie niezbędne będzie właściwe informowanie świadka nie tylko poprzez wyrażone językiem prawnym pouczenie o treści przepisu, ale także wyjaśnienie wątpliwości świadka, które mogą powstać. Wątpliwości te nie zawsze mogą wiązać się z treścią udzielonego pouczenia, a więc ich wyjaśnienie będzie także stanowić wyraz realizacji zasady lojalności procesowej ${ }^{9}$. Pamiętać bowiem należy, że świadek w życiu codziennym będzie także wskazywał miejsce zamieszkania w celu realizacji innych obowiązków nałożonych przepisami prawa. Mam tutaj na myśli chociażby obowiązek składania rocznych zeznań podatkowych (PIT), gdzie podaje się

${ }^{5}$ Wyrok WSA w Opolu z 19 lipca 2012 r., I SA/Op 183/12, Lex nr 1218505. Tak: K. EICHSTAEDT, Komentarz do art. 618 a k.p.k., [w:] Kodeks postepowania karnego. Komentarz, t. II, red. D. Świecki, Warszawa: Wolters Kluwer Polska 2017, s. 1306.

${ }^{6}$ K. DudKA, Komentarz do art. 618 a k.p.k., [w:] Kodeks postepowania karnego. Komentarz, red. K. Dudka, Warszawa: Wolters Kluwer Polska 2018, s. 1643.

${ }^{7}$ Tamże.

${ }^{8}$ K. EichSTAEDT, Komentarz do art. 618 a k.p.k., [w:] Kodeks, red. D. Świecki, s. 1306. Podobnie: postanowienie NSA z 13 maja 2011 r., I OW 11/11, LEX nr 1081105; wyrok WSA w Gliwicach z dnia 23 lutego 2017 r., I SA/Gl 1131/169, LEX nr 2252004.

${ }^{9}$ Szerzej na temat zasady lojalności procesowej zob.: M. ŻBIKOWSKA, Zasada lojalności w procesie karnym (odniesiona do pokrzywdzonego), Torun: Wydawnictwo Adam Marszałek 2015, s. 89-95. 
miejsce zamieszkania, czy też uiszczanie według miejsca zamieszkania opłaty za gospodarowanie odpadami komunalnymi.

W kontekście stanu epidemii SARS-CoV-2 zaznaczyć należy, że świadek może przebywać $\mathrm{w}$ innym miejscu niż miejsce zamieszkania np. $\mathrm{z}$ uwagi na odbywanie kwarantanny przez pozostałych domowników (osób zamieszkujących w tej samej nieruchomości co świadek). Świadek, nie chcąc zostać objęty kwarantanną z pozostałymi domownikami, wówczas mógł podjąć decyzję o czasowej zmianie miejsca pobytu. Ze względów organizacyjnych i/lub finansowych może to być miejsce oddalone od miejsca zamieszkania. Takie miejsce bez wątpienia nie będzie miejscem zamieszkania w rozumieniu art. 25 Kodeksu cywilnego, gdyż z uwagi na charakter opisanej sytuacji, świadek nie ma zamiaru stałego pobytu $\mathrm{w}$ tej miejscowości, pobyt zaś ograniczy się do okresu kwarantanny pozostałych domowników. Wydaje się, że przytoczona sytuacja jest zbliżona do stanu faktycznego, który był już przedmiotem rozważań doktryny. W literaturze powszechnie wskazuje się, że niejednokrotnie bowiem świadek rozpoczyna swoją podróż do miejsca wykonania czynności postępowania ,nie bezpośrednio z miejsca swojego zamieszkania, lecz np. z miejscowości, w której znajduje się w związku z delegacją służbową, którą musi przerwać, aby stawić się na wezwanie sądu, czy też z miejsca wypoczynku, który wcześniej zaplanował i opłacił"10. Zgodzić należy się z K. Eichstaedtem, że każdą z takich sytuacji należy oceniać indywidualnie i „,co do zasady należy jednak przyjąć, iż świadkowi w zaistniałych przypadkach będzie przysługiwał zwrot kosztów podróży, mimo iż podróż na wezwanie organu procesowego nie będzie prowadzona z miejsca zamieszkania świadka w rozumieniu art. 25 k.c." ${ }^{11}$. Wydaje się więc, że opisana powyżej sytuacja, związana ze stanem epidemii SARS-CoV-2, także będzie umożliwiała zwrot świadkowi kosztów podróży z miejsca, w którym aktualnie przebywa, pomimo iż nie jest to miejsce zamieszkania świadka.

\footnotetext{
${ }^{10}$ K. EichSTAeDt, Komentarz do art. 618 a k.p.k., [w:] Kodeks, red. D. Świecki, s. 1306. Podobnie: K. Nowicki, Komentarz do art. 618 a k.p.k., [w:] Kodeks postępowania karnego. Komentarz, red. J. Skorupka, Warszawa: C.H. Beck 2015, s. 1859; S. STEInBORN, Komentarz do art. 618 a k.p.k., [w:] Kodeks postepowania karnego. Komentarz, t. II, red. L.K. Paprzycki, Warszawa: Wolters Kluwer Polska 2013, s. 1465. Podobnie: A. WAŻNY, Komentarz do art. 618 a k.p.k., [w:] Kodeks postepowania karnego. Komentarz, red. A. Sakowicz, Warszawa: C.H. Beck 2015, s. 1513; P. GENSIKOWSKI, Komentarz do art. 618 a k.p.k., [w:] Kodeks postepowania karnego. Komentarz, t. II, red. D. Drajewicz, Legalis 2020 [dostęp: 20.10.2020].

${ }^{11}$ K. EichSTAEDT, Komentarz do art. 618 a k.p.k., [w:] Kodeks, red. D. Świecki, s. 1306.
} 


\section{CELOWE I RACJONALNE KOSZTY PRZEJAZDU ŚWIADKA}

Przepis art. 618a § 1 k.p.k. wskazuje, że zwrot świadkowi kosztów podróży następuje w wysokości rzeczywiście poniesionych racjonalnych i celowych kosztów przejazdu własnym samochodem lub innym odpowiednim środkiem transportu. Ustawa wprowadza więc bardzo ogólną regulację. Pewnym uszczegółowieniem jest sformułowanie w $§ 2$ górnej granicy należności, która odnosi się do wysokości kosztów przysługujących pracownikowi zatrudnionemu w państwowej lub samorządowej jednostce sfery budżetowej z tytułu podróży służbowej na obszarze kraju ${ }^{12}$. W pierwszej kolejności zauważyć należy, że obecne brzmienie przepisu w sposób istotny różni się od poprzedniej regulacji. Art. 4 ust. 1 dekretu z dnia 26 października 1950 r. o należnościach świadków, biegłych i stron w postępowaniu sądowym stanowił bowiem, że za koszty podróży uznaje się koszty przejazdu środkiem transportu masowego (koleją, autobusem itp.) w klasie najniższej, w braku zaś takiego środka - koszty przejazdu najtańszym z dostępnych środków lokomocji. Ponadto art. 3 przedmiotowego dekretu wprowadza liczne ograniczenia w zakresie zwrotu świadkowi kosztów podróży. Otóż świadek zamieszkały w miejscowości oddalonej ponad $10 \mathrm{~km}$ od miejsca wykonywania czynności urzędowej, do której został wezwany, mógł żądać zwrotu kosztów podróży od miejsca jego zamieszkania do miejsca wykonywania czynności i z powrotem. Sąd mógł jednak przyznać zwrot kosztów podróży świadkowi zamieszkałemu bliżej niż $10 \mathrm{~km}$, wszakże w odległości nie mniejszej niż $4 \mathrm{~km}$ od miejsca wykonywania czynności urzędowej, jeżeli przemawiają za tym względy słuszności.

Zmiana omawianych regulacji jest więc kluczowa i bez wątpienia przystająca do współczesnych realiów społeczno-gospodarczych. Kluczowe z punktu widzenia dalszych rozważań jest więc wskazanie, jak należy interpretować racjonalność i celowość w zakresie wyboru środka transportu. Wybór środka transportu należy do świadka, jednak musi on liczyć się z tym, że organ procesowy nie dokona zwrotu kosztów w wysokości żądanej przez świadka. Ocena racjonalności i celowości w wyborze środka transportu nie wiąże się z wyborem najtańszego środka transportu, co wynika $\mathrm{z}$ analizy zmian wprowadzonych przez ustawodawcę, a omówionych powyżej. W tym zakresie poddać należy analizie poglądy doktryny oraz orzecznictwo.

\footnotetext{
${ }^{12}$ Kwestię tą reguluje rozporządzenie Ministra Infrastruktury z 25.03.2002 r. w sprawie warunków ustalania oraz sposobu dokonywania zwrotu kosztów używania do celów służbowych samochodów osobowych, motocykli i motorowerów niebędących własnością pracodawcy (Dz.U. Nr 27, poz. 271 ze zm.). W rozporządzeniu przewidziano stawkę za $1 \mathrm{~km}$ przebiegu samochodu o pojemności silnika do $900 \mathrm{~cm}^{3}-0,5214 \mathrm{z}$, natomiast o pojemności powyżej $900 \mathrm{~cm}^{3}-0,8358 \mathrm{zł}$.
} 
K. Dudka ${ }^{13}$ i P. Gensikowski ${ }^{14}$ wskazali, że koszt podróży nie może być jedynym ani głównym kryterium zasadności wyboru określonego środka transportu, gdyż istotne są również takie kryteria, jak czas podróży, warunki, konieczność korzystania z kilku środków transportu, konieczność przesiadek, czas przyjazdu na miejsce czynności w powiązaniu z czasem jej rozpoczęcia, cechy osobiste świadka (wiek, stan zdrowia, niepełnosprawność). S. Steinborn ${ }^{15} \mathrm{~W}$ ocenie racjonalności i celowości wyboru środka transportu podkreślił konieczność zindywidualizowania tejże oceny, chociażby na podstawie kryterium znaczących odległości (zasadność wyboru transportu lotniczego), kryterium o charakterze logistycznym/ organizacyjnym (czas podróży, warunki, przesiadki, czas oczekiwania i czas powrotu) oraz kryterium odnoszącym się do cech osobistych świadka (wiek, stan zdrowia, niepełnosprawność). K. Nowic$\mathrm{ki}^{16}$ zwrócił natomiast uwagę na bardziej złożony charakter przedmiotowego zagadnienia, wskazując, że ocena celowości będzie następowała z uwzględnieniem wielu czynników, np. stanu zdrowia świadka, jego wieku, niepełnosprawności. Cytowany autor zwrócił także uwagę, że „powinno się uwzględnić niedogodności, jakie mogą wiązać się z podróżowaniem komunikacją publiczną, np. konieczność podróżowania nocą, aby zdążyć na czas wykonywania czynności, potrzebę długiego oczekiwania na dokonanie czynności po przybyciu danym środkiem transportu, czy też długiego oczekiwania na połączenie do miejsca zamieszkania już po dokonaniu czynności procesowej”, ale także konieczność dokonywania przesiadek ${ }^{17}$. K. Eichstaedt stwierdził, że za „wątpliwe uznać należy żądanie świadka przyznania zwrotu kosztów przejazdu własnym samochodem w sytuacji, gdy istnieje dogodne połączenie autobusem lub pociągiem" ${ }^{18}$. Cytowany autor podkreślił jednak istnienie dodatkowych kryteriów oceny celowości i racjonalności, przyjęte w orzecznictwie sądowym, o którym będzie mowa poniżej ${ }^{19}$. A. Ważny wskazał z kolei na ocenę kwestii „przybycia na czas, wynikający z terminu wezwania liczonego od jego doręczenia, biorąc pod uwagę sprawne i uzasadnione sytuacją osobistą świadka dotarcie do sądu lub organu"20.

${ }^{13}$ K. DudKA, Komentarz do art. 618 a k.p.k., [w:] Kodeks, red. K. Dudka, s. 1642.

${ }^{14}$ P. GensiKOwSKI, Komentarz do art. 618 a k.p.k., [w:] Kodeks, red. D. Drajewicz [dostęp: 20.10.2020].

${ }^{15}$ S. STEInBORn, Komentarz do art. 618 a k.p.k., [w:] Kodeks, red. L.K. Paprzycki, s. 1466.

${ }^{16}$ K. Nowicki, Komentarz do art. 618 a k.p.k., [w:] Kodeks, red. J. Skorupka, s. 1859.

${ }^{17}$ Tamże.

${ }^{18}$ K. EichSTAEDT, Komentarz do art. 618 a k.p.k., [w:] Kodeks, red. D. Świecki, s. 1307.

${ }^{19}$ Tamże.

${ }^{20}$ A. WAŻNY, Komentarz do art. 618 a k.p.k., [w:] Kodeks, red. A. Sakowicz, s. 1514. 
Korzystanie z dodatkowych kryteriów do oceny racjonalności i celowości wyboru środka transportu przez świadka znajduje także uzasadnienie w stanowiskach wyrażonych w orzecznictwie.

W pierwszej kolejności przytoczyć należy pogląd wyrażony przez Sąd Najwyższy w postanowieniu z 21 lipca 2016 r. ${ }^{21}$ Sąd uznał, że unormowanie art. 618a k.p.k. przyznaje świadkowi prawo wyboru środka transportu, lecz nie ma ono charakteru nieograniczonego. Wybór jest limitowany względami racjonalności i celowości. Wskazał bowiem, że:

jeżeli dostępne są środki transportu prywatnego i publicznego i oba gwarantują stawiennictwo świadka w sądzie $w$ wyznaczonym terminie oraz zbliżony czas i warunki podróży bez nadmiernego oczekiwania w sądzie na rozpoczęcie czynności procesowej, to cechy racjonalności, jeżeli nie przeciwstawiają się temu względy na okoliczności osobiste dotyczące świadka, powinny spowodować, iż świadek odbędzie podróż do sądu środkami transportu publicznego ${ }^{22}$.

Sąd w uzasadnieniu przedmiotowego postanowienia wskazał także, że „osobiste cechy świadka nie wskazywały też na to, aby korzystanie przez świadka ze środka transportu droższego i wygodniejszego było uzasadnione" ${ }^{23}$. Powstaje natomiast pytanie, czy sąd dokonał analizy tych okoliczności, czy zgodnie z przytoczoną powyżej zasadą lojalności procesowej prawidłowo ustalił stan faktyczny? Trudno bowiem oczekiwać, że świadek sam będzie znał szczegółowe zasady dotyczące zwrotu kosztów. W praktyce marginalne jest także korzystanie przez świadka z pełnomocnika. Nie dziwi więc fakt, że w sprawie będącej przedmiotem analiz Sądu Najwyższego, świadek wskazała na pewne okoliczności dopiero w zażaleniu. Ponadto, sąd stwierdził, że w żaden sposób tych okoliczności nie udokumentowała. Rodzi się więc drugie pytanie, na które nie sposób odpowiedzieć bez szczegółowej analizy akt sprawy, co jednak wykracza poza zakres niniejszego opracowania.

W tym miejscu warto przytoczyć także tezę z postanowienia Sądu Apelacyjnego w Katowicach z 18 stycznia 2017 r., który stwierdził, że przedmiotowy wybór jest limitowany względami racjonalności i celowości. W pierwszej kolejności zdaniem Sądu należy wziąć pod uwagę, jakie środki transportu w określonym wypadku są dostępne. Jeżeli dostępne są środki transportu prywatnego i publicznego, a oba gwarantują stawiennictwo świadka w sądzie

${ }^{21}$ Postanowienie Sądu Najwyższego z dnia 21 lipca 2016 r., WZ 14/16, OSNKW 2016/10, poz. 69, LEX nr 2071906.

${ }^{22}$ Tamże.

${ }^{23}$ Tamże. 
w wyznaczonym terminie oraz zbliżony czas i warunki podróży, to jeżeli nie przeciwstawia się temu wzgląd na okoliczności osobiste dotyczące świadka (np. choroba, ciąża czy wyjątkowo trudny dojazd na przystanek), celowy i racjonalny jest wybór środków transportu publicznego ${ }^{24}$. Na kanwie przytoczonego orzeczenia K. Dudka ${ }^{25}$ uznała, że nie można zaaprobować tego poglądu $\mathrm{w}$ zakresie zobligowania do skorzystania przede wszystkim z komunikacji publicznej. Należy jednak zwrócić uwagę, że stanowisko Sądu Apelacyjnego w Katowicach wyrażone w uzasadnieniu do omawianego postanowienia zawiera uszczegółowienie pierwotnie postawionej tezy. Sąd zwrócił bowiem uwagę na zbliżony czas i warunki podróży, a ponadto na względy osobiste świadka. Ten szerszy kontekst pokazuje, że przedmiotowe postanowienie koresponduje $\mathrm{z}$ poglądami wyrażonymi w doktrynie.

Mając na uwadze powyższe, przytoczyć należy inne orzeczenie Sądu Apelacyjnego w Katowicach. W postanowieniu z 27 listopada 2013 r. Sąd słusznie zauważył, że koszt podróży nie może być jednak jedynym ani głównym kryterium zasadności wyboru określonego środka transportu. Istotne są również kryteria takie, jak: czas podróży, warunki, konieczność korzystania z kilku środków transportu lub konieczność przesiadek, czas przyjazdu na miejsce czynności w korelacji z czasem jej rozpoczęcia. Nie bez znaczenia są również osobiste cechy świadka, takie jak: wiek, stan zdrowia, niepełnosprawność, które mogą uzasadniać skorzystanie z droższego i wygodniejszego środka transportu ${ }^{26}$. Tożsamy pogląd został także wyrażony w wyroku Sądu Apelacyjnego w Katowicach z 25 maja 2017 r. $^{27}$

Na kanwie rozważań odnoszących się do celowości i racjonalności kosztów przejazdu świadka zauważyć także należy, że kwestia zwrotu poniesionych kosztów podróży jest niezależna od miejscowości zamieszkania świadka. Sąd

\footnotetext{
${ }^{24}$ Postanowienie Sądu Apelacyjnego w Katowicach z dnia 18 stycznia 2017 r., II AKz 23/17, LEX nr 2309516.

${ }^{25}$ K. DUDKA, Komentarz do art. 618 a k.p.k., [w:] Kodeks, red. K. Dudka, s. 1642. Por. P. GENSIKOWSKI, Komentarz do art. 618 a k.p.k., [w:] Kodeks, red. D. Drajewicz [dostęp: 20.10.2020].

${ }^{26}$ Postanowienie SA w Katowicach z 27 listopada 2013 r., II AKz 723/13, LEX nr 1422535. Podobnie: K. EichSTAEDT, Komentarz do art. 618 a k.p.k., [w:] Kodeks, red. D. Świecki, s. 1307; K. Nowicki, Komentarz do art. 618 a k.p.k., [w:] Kodeks, red. J. Skorupka, s. 1859; K. DUDKA, Komentarz do art. 618 a k.p.k., [w:] Kodeks, red. K. Dudka, s. 1642; S. STEINBORN, Komentarz do art. 618 a k.p.k., [w:] Kodeks, red. L.K. Paprzycki, s. 1466; P. GENSIKOwsKI, Komentarz do art. 618 a k.p.k., [w:] Kodeks, red. D. Drajewicz [dostęp: 20.10.2020]; D. SzuMiŁo-KuLCZYCKA, Komentarz do art. 618 a k.p.k., [w:] Kodeks postępowania karnego. Komentarz orzeczniczy, red. K. Dudka, H. Paluszkiewicz D. Szumiło-Kulczycka, LEX 2015 [dostęp: 20.10.2020].

${ }^{27}$ Wyrok Sądu Apelacyjnego w Katowicach z dnia 25 maja 2017 r., II AKa 141/17, Legalis nr 1658162.
} 
Apelacyjny w Lublinie słusznie orzekł, że jeżeli świadek przybył do sądu na wezwanie $\mathrm{z}$ miejscowości położonej za granicą, przysługuje mu zwrot faktycznie poniesionych kosztów ${ }^{28}$.

$\mathrm{Na}$ marginesie warto dodać, że świadkowi przysługuje prawo do zwrotu kosztów dojazdu do sądu w związku z wezwaniem, jednak za niedopuszczalne należy uznać przyznanie świadkowi zwrotu kosztów podróży do sądu, aby odebrać wezwanie na rozprawę ${ }^{29}$.

\section{OCENA RACJONALNOŚCI I CELOWOŚCI WYBORU ŚRODKA TRANSPORTU W STANIE EPIDEMII SARS-COV-2}

Zagadnienie dotyczące zwrotu kosztów podróży z miejsca zamieszkania świadka do miejsca wykonywania czynności postępowania zyskuje jednak na aktualności z perspektywy ogłoszonego stanu epidemii wywołanego zakażeniami wirusem SARS-CoV-2. Ustawa o zapobieganiu oraz zwalczaniu zakażeń i chorób zakaźnych u ludzi ${ }^{30}$ wprowadza szczegółowe regulacje w zakresie stanu zagrożenia epidemicznego i stanu epidemii. Zgodnie $\mathrm{z}$ art. 46 przedmiotowej ustawy stan zagrożenia epidemicznego lub stan epidemii na obszarze województwa lub jego części ogłasza i odwołuje wojewoda, w drodze rozporządzenia, na wniosek państwowego wojewódzkiego inspektora sanitarnego. Jeżeli zagrożenie epidemiczne lub epidemia występuje na obszarze więcej niż jednego województwa, stan zagrożenia epidemicznego lub stan epidemii ogłasza i odwołuje, w drodze rozporządzenia, minister właściwy do spraw zdrowia w porozumieniu z ministrem właściwym do spraw administracji publicznej, na wniosek Głównego Inspektora Sanitarnego. W rozporządzeniach tych, uwzględniając drogi szerzenia się zakażeń i chorób zakaźnych oraz sytuację epidemiczną na obszarze, na którym ogłoszono stan zagrożenia epidemicznego lub stan epidemii, można ustanowić m.in.: czasowe ograniczenie określonego sposobu przemieszczania się, czy też czasowe ograniczenie funkcjonowania określonych instytucji lub zakładów pracy. Rozporządzenia wprowadziły

${ }^{28}$ Wyrok Sądu Apelacyjnego w Lublinie z dnia 10 maja 1994 r., II AKz 106/94, LEX nr 21289. Podobnie: K. EichSTAEDT, Komentarz do art. 618 a k.p.k., [w:] Kodeks, red. D. Świecki, s. 1308; S. STEInBORn, Komentarz do art. 618 a k.p.k., [w:] Kodeks, red. L.K. Paprzycki, s. 1467; A. WAŻNY, Komentarz do art. 618 a k.p.k., [w:] Kodeks, red. A. Sakowicz, s. 1513.

${ }^{29}$ Postanowienie SA w Katowicach z dnia 26 czerwca 2013 r., II AKz 346/13, LEX nr 1378322. Podobnie K. EIChSTAEDT, Komentarz do art. 618 a k.p.k., [w:] Kodeks, red. D. Świecki, s. 1308.

${ }^{30}$ Ustawa z dnia 5 grudnia 2008 r. o zapobieganiu oraz zwalczaniu zakażeń i chorób zakaźnych u ludzi, t. j. Dz.U. z 2019 r., poz. 1239. 
ograniczenia $\mathrm{w}$ funkcjonowaniu organów administracji publicznej. Jako przykład można podać chociażby § 10 Rozporządzenia Ministra Zdrowia z dnia 20 marca 2020 r. w sprawie ogłoszenia na obszarze Rzeczypospolitej Polskiej stanu epidemii (Dz.U. z 2020 r., poz. 491).

Kluczowe znaczenie ma jednak ustawa $\mathrm{z}$ dnia 31 marca 2020 r. o zmianie ustawy o szczególnych rozwiązaniach związanych z zapobieganiem, przeciwdziałaniem i zwalczaniem COVID-19, innych chorób zakaźnych oraz wywołanych nimi sytuacji kryzysowych, oraz niektórych innych ustaw (Dz.U. z 2020 r., poz. 568), czy też ustawa z dnia 16 kwietnia 2020 r. o szczególnych instrumentach wsparcia $\mathrm{w}$ związku $\mathrm{z}$ rozprzestrzenianiem się wirusa SARS-CoV-2 (Dz.U. z 2020 r., poz. 695). Regulacje te dotyczą w szczególności postępowań sądowych, biegu terminów, załatwiania spraw pilnych itp. Przepisy te umożliwiają prowadzenie postępowań sądowych także w stanie epidemii i mają na celu uniknięcie sytuacji, które generowałyby ujemne konsekwencje dla uczestników procesu. Brak jest gruntownych zmian przepisów dotyczących zwrotu świadkom kosztów podróży, jednak kwestia ta wymaga odniesienia właśnie z perspektywy wyzwań, które przed świadkami stawia stan epidemii. Kluczowe wydają się dwa aspekty przedmiotowego zagadnienia. Po pierwsze - wskazać należy na wybór środka transportu. Obok przesłanek oceny racjonalności i celowości wyboru środka transportu sformułowanych w orzecznictwie i piśmiennictwie, pojawi się bowiem nowa okoliczność, związana z cechami osobistymi świadka. Mam tutaj na myśli względy medyczne, czyli pozostawanie w grupie ryzyka zakażeniem, ale także względy psychologiczne, tj. obawa przed zakażeniem, nawet w odniesieniu do osób, które nie znajdują się w grupie ryzyka. Wydaje się także, że można wyróżnić również okoliczności niezwiązane wprost z cechą osobistą danego świadka, lecz z sytuacją epidemiologiczną na danym terenie, np. obszarze właściwości danego sądu. Stosowanie różnych klasyfikacji, w tym klasyfikacji na żółte i czerwone powiaty (wprowadzony w IV kwartale 2020 r.) powinno wpływać na ocenę organu podejmującego decyzję o zwrocie kosztów. Pamiętać przecież należy na ograniczenia wprowadzone w środkach transportu publicznego, co może determinować skorzystanie przez świadka z prywatnego/,własnego” samochodu.

W kontekście stanu epidemii SARS-CoV-2 ważne jest więc zagadnienie „własności” samochodu. Powstaje bowiem kwestia korzystania z samochodu pożyczonego np. od członka rodziny w sytuacji, gdy własny samochód świadek pozostawił $\mathrm{w}$ domu, w którym pozostali domownicy odbywają kwarantannę, zaś świadek nie został na nią skierowany i ze względów zawodowych czasowo przebywa w innym miejscu zamieszkania. Art. $618 \mathrm{a} \S 1$ k.p.k. odnosi 
się bowiem do przejazdu „własnym samochodem”. K. Eichstaedt stwierdził, że przepis ten umożliwia ,zwrot kosztów przejazdu własnym samochodem, co oznacza, iż nie ma podstaw do żądania zwrotu kosztów przejazdu samochodem pożyczonym"31. Odmienny pogląd wyraził S. Steinborn, który uznał, że poprzez brzmienie omawianego przepisu ustawodawca zaakcentował, że „,nie podlega zwrotowi koszt wynajmu samochodu, w celu dojazdu na miejsce czynności”32. Cytowany autor dodał, że „pojęcie «własny» nie należy interpretować zbyt rygorystycznie i względy celowościowe przemawiają za dopuszczalnością zwrotu kosztów przejazdu również samochodem użyczonym (bezpłatnie) świadkowi przez inną osobę np. członka rodziny, znajomego, o ile nie ma wątpliwości, że świadek rzeczywiście nim przybył”33. Zbliżony pogląd wyraził P. Gensikowski wskazując, że „świadek nie ma prawa żądać zwrotu kosztu najmu środka transportu nienależącego do niego", jednakże użycie przymiotnika „własny” nie oznacza natomiast, że „świadkowi nie przysługuje zwrot kosztów podróży, a więc np. koszt kupna paliwa, które świadek zużył $\mathrm{w}$ trakcie podróży obcym samochodem na wezwanie organu prowadzącego postępowanie" 34 .

Analizując przedmiotową kwestię, można wskazać kilka sytuacji faktycznych, które wygenerują swoisty problem przy tak rygorystycznej wykładni pojęcia „własny samochód”, jak wskazano to powyżej. Przykładowo można przytoczyć sytuacje: 1) właścicielem jedynego samochodu w gospodarstwie domowym jest drugi małżonek, gdyż nabył go przed zawarciem związku małżeńskiego lub była to darowizna wstępnych do majątku odrębnego; 2) właścicielem jedynego samochodu w gospodarstwie domowym jest wstępny, który użyczył go świadkowi na czas nieokreślony; 3) właścicielem jedynego samochodu w gospodarstwie domowym jest zstępny, gdyż świadek (rodzic) dokonał darowizny na jego rzecz. Przyjęcie więc rygorystycznej wykładni stanowiłoby swoiste reductio ad absurdum, gdyż świadek nie mógłby otrzymać zwrotu kosztów przejazdu samochodem, z którego w sensie faktycznym korzysta w życiu codziennym. Mając na uwadze powyższe, za zasadny uznać należy pogląd wyrażony przez S. Steinborna, który stwierdził, że omawianego przepisu „nie należy interpretować zbyt rygorystycznie i względy celowościowe

\footnotetext{
${ }^{31}$ K. EichSTAEDT, Komentarz do art. 618 a k.p.k., [w:] Kodeks, red. D. Świecki, s. 1307.

${ }^{32}$ S. SteInBORn, Komentarz do art. 618 a k.p.k., [w:] Kodeks, red. L.K. Paprzycki, s. 1466.

${ }^{33}$ Tamże.

${ }^{34}$ P. GensikowsKi, Komentarz do art. 618 a k.p.k., [w:] Kodeks, red. D. Drajewicz [dostęp: 20.10.2020].
} 
przemawiają za dopuszczalnością zwrotu kosztów przejazdu również samochodem użyczonym (bezpłatnie) świadkowi przez inną osobę"35.

W tym zakresie postulować należy de lege ferenda zmianę art. 618a § 1 k.p.k. poprzez usunięcie przymiotnika „własny”. Ma to także istotny walor w kontekście stanu epidemii SARS-CoV-2. Być może osoba nieposiadająca samochodu i niemogąca go użyczyć od osób najbliższych czy znajomych, w świetle przedmiotowych zagrożeń zdecydowałaby się wynająć samochód. Na tę kwestię spojrzeć bowiem należy przez przytoczone powyżej względy medyczne, czyli pozostawanie w grupie ryzyka zakażeniem, czy też względy psychologiczne, tj. obawa przed zakażeniem, nawet w odniesieniu do osób, które nie znajdują się w grupie ryzyka. Nieuwzględnienie tych aspektów może bowiem prowadzić do niestawiennictwa świadka na rozprawie (przedstawienie usprawiedliwienia), co wpłynie na przewlekłość postępowania.

\section{WNIOSKI}

Dokonana powyżej analiza miała na celu odniesienie się do problematyki zwrotu kosztów podróży przysługujący świadkowi w trybie art. 618a k.p.k. w kontekście stanu epidemii SARS-CoV-2. Przedstawiono więc kluczowe aspekty w zakresie zwrotu kosztów przejazdu świadka, jak ocena miejsca zamieszkania czy też ocena racjonalności i celowości wyboru środka transportu. Tematyka ta, mimo że w niektórych kwestiach budzi wątpliwości interpretacyjne, nie znalazła szerszego odniesienia w piśmiennictwie. Stąd też aktualności nabiera dyskusja nad regulacją art. 618a k.p.k. właśnie w kontekście stanu epidemii SARS-CoV-2. W niniejszym opracowaniu wskazałem więc na konieczność uwzględniania dodatkowych okoliczności w świetle nowych zagrożeń epidemiologicznych. Ma to dać świadkowi komfort uczestniczenia w procesie, a tym samym przeciwdziałać przewlekłości postępowania. Pamiętać bowiem należy skalę zaległości po ogłoszonym „lockdownie” w drugim kwartale 2020 r. Zbliżona sytuacja wystąpiła w czwartym kwartale 2020 r. i pierwszym kwartale 2021 r., natomiast jej genezą był brak stawiennictwa uczestników postępowania (w tym świadków) w konsekwencji kwarantanny lub zakażenia SARS-CoV-2.

W tym zakresie wskazać należy na pilną nowelizację przepisów kodeksu postępowania karnego umożliwiającą szersze wykorzystanie wideokonferencji. Mam tutaj na myśli nie tylko przesłuchanie świadka, lecz także udział

\footnotetext{
${ }^{35}$ S. SteinBorn, Komentarz do art. 618 a k.p.k., [w:] Kodeks, red. L.K. Paprzycki, s. 1466.
} 
innych uczestników postępowania w tej formie (zdalna rozprawa). Obecne regulacje art. $177 \S 1$ a k.p.k. umożliwiające przesłuchanie świadka w drodze wideokonferencji są dalece niefunkcjonalne. Wymagają bowiem udania się przez świadka do budynku sądu i udział w tej czynności referendarza sądowego, asystenta sędziego lub urzędnika zatrudnionego w sądzie. W literaturze zgłaszano potrzebę zmian w kierunku odformalizowania i elektronizacji procesu karnego w poszczególnych jego obszarach ${ }^{36}$.

Dostrzegalna jest jednak istotna zmiana wynikająca właśnie ze stanu epidemii SARS-CoV-2, który skutecznie sparaliżował w 2020 r. wymiar sprawiedliwości. Zmiany chociażby art. $250 \S 3 \mathrm{a}-\S 3$ h k.p.k., art. $374 \S 3$ i $\S 4$ k.p.k. ${ }^{37}$ pokazują, że możliwa jest ewolucja procesu karnego w newralgicznym kierun$\mathrm{ku}$, jakim jest elektronizacja. Regulacje te w dalszym ciągu mają charakter szczątkowy i jak zaobserwowałem, są traktowane w praktyce jako ekstraordynaryjne. Część z tych regulacji rozwiązuje istotne problemy dostrzegalne przy przesłuchaniu w trybie art. $177 \S 1$ a k.p.k. Art. $250 \S 3 \mathrm{c}$ k.p.k. stanowi, że $\mathrm{w}$,zdalnym” posiedzeniu aresztowym bierze udział w miejscu przebywania podejrzanego referendarz sądowy lub asystent sędziego zatrudniony w sądzie, w którego okręgu przebywa podejrzany lub funkcjonariusz Służby Więziennej, jeżeli podejrzany przebywa w zakładzie karnym lub areszcie śledczym. Niestety, fragmentaryczność regulacji pokazuje obawę ustawodawcy we wdrożeniu elektronizacji w pełnym zakresie. Co istotne, art. 374 k.p.k. różnicuje pozycję procesową stron. Przykład ten pokazuje, że zmiany mają charakter jedynie fragmentaryczny, co w mojej ocenie wpłynie na ich stosowanie w praktyce.

Pozostaje więc de lege ferenda postulować niezwłoczną, acz przemyślaną i kompleksową, elektronizację procesu karnego, która nadążałaby za wyzwaniami współczesności, w tym oczywiście kluczowemu wyzwaniu lat 2020-2021 (2022?), tj. epidemii SARS-CoV-2.

${ }^{36}$ Zob. m.in.: J. KosowsKI, Sposoby przyspieszenia postępowania w świetle wybranych zasad naczelnych procesu karnego, [w:] W obliczu reformy sadownictwa w Polsce. Gtówne problemy postępowań sądowych, red. D. Gil, A. Piasecki, Kraków: Wydawnictwo Naukowe Uniwersytetu Pedagogicznego w Krakowie 2019, s. 41-62; TENŻE, Doręczenia w procesie karnym a kwestia odformalizowania postępowania sądowego, [w:] W kierunku odformalizowania postępowania sądowego, red. D. Gil, Lublin: Wydawnictwo KUL 2017, s. 67-82; TENŻE, Odformalizowanie i elektronizacja jako kierunek rozwoju postępowania karne, [w:] e-Wymiar sprawiedliwości $w$ aspekcie europejskim, red. B. Śliwczyński, L. Łuczak-Noworolnik, Poznań: Instytut Logistyki i Magazynowania w Poznaniu 2016, s. 99-108; TENŻE, Formalizm procesowy w świetle zmian kodeksu postępowania karnego, [w:] Reforma procesu karnego w świetle jego zasad, red. D. Gil, E. Kruk, Lublin: Wydawnictwo KUL 2016, s. 204-217.

${ }^{37}$ Wprowadzone ustawą z dnia 19 czerwca 2020 r. o dopłatach do oprocentowania kredytów bankowych udzielanych przedsiębiorcom dotkniętym skutkami COVID-19 oraz o uproszczonym postępowaniu o zatwierdzenie układu w związku z wystąpieniem COVID-19, Dz.U. z 2020 r., poz. 1086. 


\section{BIBLIOGRAFIA}

\section{ŹRÓDŁA PRAWA}

Ustawa z dnia 19 czerwca 2020 r. o dopłatach do oprocentowania kredytów bankowych udzielanych przedsiębiorcom dotkniętym skutkami COVID-19 oraz o uproszczonym postępowaniu o zatwierdzenie układu w związku z wystąpieniem COVID-19, Dz.U. z 2020 r., poz. 1086.

Ustawa z dnia 31 marca 2020 r. o zmianie ustawy o szczególnych rozwiązaniach związanych z zapobieganiem, przeciwdziałaniem i zwalczaniem COVID-19, innych chorób zakaźnych oraz wywołanych nimi sytuacji kryzysowych oraz niektórych innych ustaw, Dz.U. z 2020 r., poz. 568.

Ustawa z dnia 16 kwietnia 2020 r. o szczególnych instrumentach wsparcia w związku z rozprzestrzenianiem się wirusa SARS-CoV-2, Dz.U. z 2020 r., poz. 695.

Ustawa z dnia 31 sierpnia 2012 r. o zmianie ustawy - Kodeks postępowania karnego oraz niektórych innych ustaw, Dz.U. z 2012 r., poz. 1101.

Ustawa z dnia 24 września 2010 r. o ewidencji ludności, t.j. Dz.U. z 2019 r., poz. 1397 z późn. zm.

Ustawa z dnia 5 grudnia 2008 r. o zapobieganiu oraz zwalczaniu zakażeń i chorób zakaźnych u ludzi, t. j. Dz.U. z 2019 r., poz. 1239.

Rozporządzenie Ministra Infrastruktury z dnia 25 marca 2002 r. w sprawie warunków ustalania oraz sposobu dokonywania zwrotu kosztów używania do celów służbowych samochodów osobowych, motocykli i motorowerów niebędących własnością pracodawcy, Dz.U. Nr 27, poz. 271 ze zm.

\section{ORZECZNICTWO}

Wyrok Sądu Apelacyjnego w Katowicach z 25 maja 2017 r., II AKa 141/17, Legalis nr 1658162.

Wyrok WSA w Gliwicach z 23 lutego 2017 r., I SA/Gl 1131/169, LEX nr 2252004.

Postanowienie Sądu Najwyższego z 21 lipca 2016 r., WZ 14/16, OSNKW 2016/10, poz. 69, LEX nr 2071906.

Postanowienie SA w Katowicach z 27 listopada 2013 r., II AKz 723/13, LEX nr 1422535.

Postanowienie SA w Katowicach z 26 czerwca 2013 r., II AKz 346/13, LEX nr 1378322.

Wyrok WSA w Opolu z 19 lipca 2012 r., I SA/Op 183/12, Lex nr 1218505.

Postanowienie NSA z dnia 13 maja 2011 r., I OW 11/11, LEX nr 1081105.

Wyrok Trybunału Konstytucyjnego z 22 marca 2011 r., SK 13/08, LEX nr 785597.

Postanowienie Sądu Apelacyjnego w Katowicach z 18 stycznia 2017 r., II AKz 23/17, LEX nr 2309516.

Wyrok Sądu Apelacyjnego w Lublinie z 10 maja 1994 r., II AKz 106/94, LEX nr 21289.

\section{LITERATURA}

DUDKA Katarzyna: Komentarz do art. 618 a k.p.k., [w:] Kodeks postępowania karnego. Komentarz, red. Katarzyna Dudka, Warszawa: Wolters Kluwer Polska 2018, s. 1642-1644.

EICHSTAEDT Krzysztof: Komentarz do art. 618 a k.p.k., [w:] Kodeks postępowania karnego. Komentarz, t. II, red. Dariusz Świecki, Warszawa: Wydawnictwo Wolters Kluwer Polska 2017, s. 1305-1309.

GENSIKOWSKI Piotr: Komentarz do art. 618 a k.p.k., [w:] Kodeks postępowania karnego. Komentarz, t. II, red. Dariusz Drajewicz, Legalis 2020 [dostęp: 20.10.2020]. 
Kosowski Jakub: Doręczenia w procesie karnym a kwestia odformalizowania postępowania sadowego, [w:] W kierunku odformalizowania postępowania sądowego, red. Damian Gil, Lublin: Wydawnictwo KUL 2017, s. 67-82.

KoSOwSKI Jakub: Formalizm procesowy w świetle zmian kodeksu postępowania karnego, [w:] Reformy procesu karnego w świetle jego zasad, red. Damian Gil, Ewa Kruk, Lublin: Wydawnictwo KUL 2016, s. 204-217.

KosOwSKI Jakub: Odformalizowanie i elektronizacja jako kierunek rozwoju postepowania karne, [w:] e-Wymiar sprawiedliwości w aspekcie europejskim, red. Bogusław Śliwczyński, Lucyna Łuczak-Noworolnik, Poznań: Instytut Logistyki i Magazynowania w Poznaniu 2016, s. 99-108.

KosowsKi Jakub: Sposoby przyspieszenia postępowania w świetle wybranych zasad naczelnych procesu karnego, [w:] W obliczu reformy sądownictwa w Polsce. Glówne problemy postępowań sqdowych, red. Damian Gil, Andrzej Piasecki, Kraków: Wydawnictwo Naukowe Uniwersytetu Pedagogicznego w Krakowie 2019, s. 41-62.

Nowicki Krzysztof: Komentarz do art. 618 a k.p.k., [w:] Kodeks postępowania karnego. Komentarz, red. Jerzy Skorupka, Warszawa: C.H. Beck 2015, s. 1858-1861.

STEINBORN Sławomir: Komentarz do art. 618 a k.p.k., [w:] Kodeks postępowania karnego. Komentarz, t. II, red. Lech K. Paprzycki, Warszawa: Wolters Kluwer Polska 2013, s. 1463-1470.

SzUMiŁo-KulCZYCKA Dobrosława: Komentarz do art. 618 a k.p.k., [w:] Kodeks postepowania karnego. Komentarz orzeczniczy, red. Katarzyna Dudka, Hanna Paluszkiewicz, Dobrosława Szumiło-Kulczycka, LEX 2015 [dostęp: 20.10.2020].

WAŻNY Andrzej: Komentarz do art. 618 a k.p.k., [w:] Kodeks postepowania karnego. Komentarz, red. Andrzej Sakowicz, Warszawa: C.H. Beck 2015, s. 1512-1514.

ŻBIKOwSKA Małgorzata: Zasada lojalności w procesie karnym (odniesiona do pokrzywdzonego), Torun: Wydawnictwo Adam Marszałek 2015.

\section{ZWROT KOSZTÓW PODRÓŻY \\ PRZYSŁUGUJACY ŚWIADKOWI W TRYBIE ART. 618A K.P.K. W KONTEKŚCIE STANU EPIDEMII SARS-COV-2}

\section{Streszczenie}

Artykuł poświęcony jest analizie problematyki zwrotu świadkowi kosztów przejazdu w trybie art. 618a k.p.k. Autor wskazuje na poglądy wyrażone w orzecznictwie i literaturze, a odnoszące się do kwestii miejsca zamieszkania świadka, ale przede wszystkim do oceny przez organ procesowy zasadności i celowości wyboru środka transportu przez świadka. Charakterystyka obowiązujących regulacji jest wstępem do dalszych analiz odnoszących się do stanu epidemii SARS-CoV-2. Obecna sytuacja epidemiologiczna wymusza bowiem uwzględnianie nowych okoliczności przez organy procesowe. $\mathrm{W}$ artykule autor wskazuje na postulaty de lege ferenda dotyczące zmiany art. 618a $\S 1$ k.p.k., ale także w ramach wniosków końcowych dostrzega potrzebę pilnej i kompleksowej nowelizacji procedury karnej zmierzającej w kierunku jej elektronizacji.

Słowa kluczowe: świadek; koszty przejazdu; celowość i racjonalność; wybór środka transportu; elektronizacja procesu karnego 


\title{
REIMBURSEMENT OF TRAVEL EXPENSES DUE \\ TO A WITNESS UNDER ART. 618A OF THE CODE OF CRIMINAL PROCEDURE IN THE CONTEXT OF THE SARS-COV-2 EPIDEMIC
}

\begin{abstract}
Su m m a ry
The article is devoted to the analysis of the issue of reimbursement of travel costs to a witness pursuant to Art. 618a of the Code of Criminal Procedure. The author points to the views expressed in the jurisprudence and literature, and relating to the issue of the witness's place of residence, but above all to the procedural authority's assessment of the legitimacy and advisability of the witness's choice of means of transport. The characteristics of the regulations in force are an introduction to further analyzes relating to the state of the SARS-CoV-2 epidemic. The current epidemiological situation forces the authorities to take into account new circumstances. In the article, the author points to de lege ferenda postulates regarding the amendment of art. 618a $\S 1$ of the Code of Criminal Procedure, but also in the final conclusions, sees the need for an urgent and comprehensive amendment to the criminal procedure aimed at its electronisation.
\end{abstract}

Keywords: witness; travel costs; purposefulness and rationality; choice of transport mode; digitalize of penal process 